This Accepted Author Manuscript is copyrighted and published by Elsevier. It is posted here by agreement between Elsevier and University of Brasilia. Changes resulting from the publishing process - such as editing, corrections, structural formatting, and other quality control mechanisms - may not be reflected in this version of the text. The definitive version of the text was subsequently published in [Flora, Volume 206, Issue 7, July 2011, Pages 676-683, doi:10.1016/j.flora.2010.11.016].You may download, copy and otherwise use the AAM for noncommercial purposes provided that your license is limited by the following restrictions:

(1) You may use this AAM for non-commercial purposes only under the terms of the CC-BY-NCND license.

(2) The integrity of the work and identification of the author, copyright owner, and publisher must be preserved in any copy.

(3) You must attribute this AAM in the following format: [agreed attribution language, including link to CC BY-NC-ND license + Digital Object Identifier link to the published journal article on Elsevier's ScienceDirect ${ }^{\circledR}$ platform].

Este Manuscrito do Autor Aceito para Publicação (AAM) é protegido por direitos autorais e publicado pela Elsevier. Ele esta disponível neste Repositório, por acordo entre a Elsevier e a Universidade de Brasília. As alterações decorrentes do processo de publicação - como a edição, correção, formatação estrutural, e outros mecanismos de controle de qualidade - não estão refletidas nesta versão do texto. A versão definitiva do texto foi posteriormente publicado em [Flora, Volume 206, Número 7, July 2011, Pages 676-683, doi:10.1016/j.flora.2010.11.016]. Você pode baixar, copiar e utilizar de outra forma o AAM para fins não comerciais, desde que sua licença seja limitada pelas seguintes restrições:

(1) Você pode usar este AAM para fins não comerciais apenas sob os termos da licença CC- BYNC-ND.

(2) A integridade do trabalho e identificação do autor, detentor dos direitos autorais e editor deve ser preservado em qualquer cópia.

(3) Tem de atribuir este AAM no seguinte formato: [acordo na linguagem atribuída, incluindo o link para CC BY-NC-ND licença Digital + DOI do artigo publicado na revista Elsevier ScienceDirect ${ }^{\circledR}$ da plataforma]. 


\title{
Distribution, structural and ecological aspects of the unusual leaf nectaries of Calolisianthus species (Gentianaceae)
}

\author{
Marina Neves Delgado \\ Luzimar Campos da Silva \\ Sônia Nair Báo \\ Helena C. Morais \\ Aristéa Alves Azevedo
}

\begin{abstract}
Nectaries in leaves of Gentianaceae have been poorly studied. The present study aims to describe the distribution, anatomy, and ecological aspects of extrafloral nectaries (EFNs) of three Calolisianthus species and in particular the ultrastructure of EFNs in Calolisianthus speciosus during leaf development, discussing its unusual structure. Leaves of Calolisianthus species were fixed and processed by the usual methods for studies using light, scanning microscopy and transmission electron microscopy (TEM). Ion chromatography was used to analyze the nectar exudates of $C$. speciosus. The distribution patterns of nectar secretion units were analysed by ANOVA and t-tests. Two EFNs that can be seen macroscopically were observed at the bases of C. speciosus and C. pendulus leaves. Such large nectaries are absent there in C. amplissimus. Another similarly large EFN is observed at the apex of each leaf in all species. The EFNs at the base of the young leaves in $\mathrm{C}$. speciosus are visited by ants during the rainy season. EFNs are formed by several nectar secretory units (nectarioles) that are present throughout the leaves. Each nectariole is formed by rosette cells with a central channel from which the nectar is released. Channels of old C. speciosus and C. pendulus EFNs were obstructed by fungi. TEM of EFNs in young leaves showed cytoplasms with secretion, small vacuoles, mitochondria, cell wall ingrowth, and plasmodesmata. TEM of EFNs in old leaves demonstrated dictyosomes, plastids, mitochondria, segments of endoplasmatic reticulum, and lipid droplets. The nectar contains sucrose, glucose and fructose.
\end{abstract}

Keywords: Calolisianthus amplissimus; Calolisianthus pendulus; Calolisianthus speciosus; Nectar secretion; Nectary anatomy; Ant-plant relationships

\section{Introduction}

Gentianaceae is the third-largest family of the order Gentianales, comprising 1650 species (Struwe and Albert, 2002). Two-thirds of the genera are distributed in the tropics (Meszáros et al., 1996). South and Central America contain the greatest diversity and considerable endemism, with 25 genera being found in Brazil (Struwe et al., 2002). Nevertheless, insufficient data about the morphology and anatomy of Gentianaceae species have limited the understanding of this family (Mészáros et al., 2002), especially for neotropical groups such as the tribe Helieae. This holds true especially with respect to leaf nectaries. Struwe et al. (2002), for instance, found calycinal colleters in many Gentianaceae species and elliptic calyx lobes with a dorsal glandular ridge, and yet no function for those structures has 
been proposed. On the other hand, Maas et al. (1984) identified the presence of extrafloral nectaries (EFNs) on calyxes as an important taxonomic attribute for the tribe Lysiantheae and Vogel (1998) showed EFNs on calyx of Irlbachia pendula (Mart.) P.J.M. Maas (syn. Calolisianthus pendulus Gilg).

The genus Calolisianthus (Griseb.) Gilg consists of 6-10 species distributed in Bolivia and south-eastern Brazil, occurring in areas of campos rupestres and cerrado ( Struwe et al., 2002). These species are perennial herbs that sometimes show a woody stem at the base. Leaves are sessile, often leathery, and oblong-elliptic, and the inflorescences are terminal, usually few-flowered cymes (H. Groen, unpubl.).

Extrafloral nectaries (EFNs) are specialised tissues or glands present on vegetative structures that secrete nectar (Durkee, 1982, Elias, 1983 and Koptur, 1992). EFNs occur in 93 families of flowering plants, and such plants bearing EFNs account for $30 \%$ of the species in some environments (Rudgers and Gardener, 2004). Plants bearing EFNs are visited by nectarforaging insects, especially ants, wasps, bees, flies and beetles (Cuautle and Rico-Gray, 2003, Koptur, 1992 and Oliveira and Freitas, 2004). Ants are the most common visitors to EFNs (do Nascimento and Del-Claro, 2010, Koptur, 1992 and Oliveira, 1997), and numerous experimental field studies have shown a facultative ant-plant mutualism, where ants are attracted to the nectaries and in turn offer the plant varying degrees of anti-herbivore protection (Cuautle and Rico-Gray, 2003, Katayama and Suzuki, 2003 and Rudgers, 2004).

The anatomical study of secretory structures is important for solving taxonomic problems (Metcalfe and Chalk, 1979 and Solereder, 1908), due to their huge structural variety and wide distribution in numerous taxa (Oliveira and Leitão, 1987 and Vogel, 1998). Nectary glands can also be important for understanding phylogenetic relationships of related species (e.g., Pascal et al., 2000). This is because EFNs show external morphological diversity, distinct anatomical structures, and different ways of releasing nectar (Elias, 1983). Some nectaries are formed by secretory parenchyma and nectar release occurs via stomata (Fahn, 1979a). In others, the nectar is released by cuticle rupture (Paiva et al., 2007). Furthermore, EFNs may also be nonvascularized or vascularized (Elias, 1983).

In this way, this paper aims to study the morphology, anatomy, distribution and functional ecology of EFNs presented on leaves of three Calolisianthus species (GentianaceaeHelieae) found in rocky field (campo rupestres) and savannah (cerrado) areas in Minas Gerais, Brazil, as well as the nectary ultrastructure of one of these species. 


\section{Materials and methods}

\section{Plant material and field information}

Leaf samples in different stages of development, including young leaves and senescent leaves, were collected from Calolisianthus speciosus (Cham. and Schltdl.) Gilg. and Calolisianthus pendulus (Mart.) Gilg. specimens in campos rupestres areas of the Ouro Branco mountain range, with altitudes ranging from 1321 to $1540 \mathrm{~m}$. Other leaf samples were collected from Calolisianthus amplissimus (Mart.) Gilg. specimens in cerrado areas of Paraopeba National Forest, with altitudes ranging from 763 to 769 m, in Minas Gerais, Brazil. Voucher specimens were deposited in the VIC Herbarium of the Federal University of Viçosa (UFV): C. pendulus (VIC 31361), C. amplissimus (VIC 31366), and Calolisianthus speciosus (VIC 31.362; VIC 31.363; VIC 31.364).

The cerrado is characterized by a variable physiognomy from open grassland fields to forest with discontinuous grassland patches (Eiten, 1972), as well as by strong rainfall seasonality, coupled with constantly high diurnal air temperatures. The soils are generally deep and well drained ( Medina, 1982). The nutrient-poor acid soils represent a restrictive factor for plant growth at these areas (Haridasan, 2000). The campo rupestre is characterised by a predominant physiognomy of grassland and shrubs ( Romero, 2002), as well as by seasonality of precipitation, high daily thermal amplitude, high temperature, frequent winds ( Scarano et al., 2001), low soil fertility, and soil with sandstone and quartz stone ( Giulietti et al., 1987).

\section{Nectar sugar analyses}

Samples of aerial parts of Calolisianthus speciosus were collected and kept in a humidity chamber for $3 \mathrm{~h}$. The nectar was collected using a syringe and put inside Eppendorf tubes with $100 \mu \mathrm{l}$ of distilled water. The samples were kept in an ultra-cold freezer for future analysis. Analyses were carried out with an ion exchange column (CarboPac PA10; Dionex Corp, Sunnyvale, CA, USA). The manual injection volume was $100 \mu \mathrm{l}$, and elution took place with $200 \mathrm{mM} \mathrm{NaOH}$ (flow rate: $0.2 \mathrm{ml} \mathrm{min-1)}$ in ion chromatography (Dionex). Sugars were detected by a pulse amperometric detector with a gold electrode. The concentration of each sugar was calculated from the results of the analyses using Chromeleon Software, using regression equations from standard analyses. 


\section{Distribution of extrafloral nectaries}

To evaluate the number of secretory units/area, whole leaves were cleared by immersion in a $10 \% \mathrm{NaOH}$ solution for $1 \mathrm{~h}$ and transferred to $20 \%$ sodium hypochlorite until they became translucent, which took approximately $72 \mathrm{~h}$. Samples were stained in Basic Fuchsin for 1 or $2 \mathrm{~h}$, dehydrated in an ethyl alcohol-xylol series and mounted in Permount (Berlyn and Miksche, 1976). The number of secretory units/areas was quantified using an Olympus AX70 microscope at 10x magnification. Three individuals from each species were evaluated, with one slide/individual for each leaf region. These leaf regions were: basal and apical portions and adaxial and abaxial surfaces of leaf blades which corresponded to the medium region of the leaf. The same leaf area, $1.91 \mathrm{~mm} 2$, was used in all three species. Data analysis was undertaken using Statistica 7.0. Analyses of the distribution of the secretory units on the leaves were performed for each species and were done with a t-test. One-way ANOVA was performed to compare the distribution of secretory units at leaves of the three species. Data for basal portions of the secretory units' data were log-transformed to meet assumptions of normality when using a one-way ANOVA with a Tukey's post hoc test.

\section{Light and electron microscopy}

For light microscopy, leaf samples were fixed in FAA (5\% acetic acid, 5\% formaldehyde, and ethanol 70\%), stored in 70\% ethanol (Johansen, 1940) and embedded in historesin (Leica Embedding Kit), following standard procedures. The embedded material was sectioned $5 \mu \mathrm{m}$ thick using a rotary microtome, mounted on slides, and stained with Toluidine Blue ( $O^{\prime} B$ Bien and Mccully, 1981). The histochemical tests carried out were PAS analysis for total carbohydrates (Maia, 1979), Ruthenium Red to detect acid polysaccharides and Sudan Red B for total lipids (Johansen, 1940).

For scanning electron microscopy (SEM), samples were fixed in a solution containing $2 \%$ glutaraldehyde, $2 \%$ paraformaldehyde, and $3 \%$ sucrose in $0.1 \mathrm{M}$ sodium cacodylate buffer ( $\mathrm{pH} 7.2$ ), dehydrated by increasing ethyl alcohol series, critical point dried in $\mathrm{CO} 2$, gold coated and observed in a 1430 LEO VP scanning electron microscope, at an accelerating voltage of 5.0 kV.

For examination by transmission electron microscopy, samples of Calolisianthus speciosus were fixed in $2.5 \%$ glutaraldehyde in $0.05 \mathrm{M}$ phosphate buffer ( $\mathrm{pH} 7.2$ ) for $24 \mathrm{~h}$. 
After fixation, cells were rinsed in the same buffer and post-fixed in $1 \%$ osmium tetroxide in $0.05 \mathrm{M}$ phosphate buffer and uranyl acetate. The material was dehydrated in a graded acetone series (30-100\%) and embedded in Spurr resin. Ultrathin sections were observed in a Jeol ${ }^{\circledR}$ 1011 transmission electron microscope at $80 \mathrm{kV}$.

\section{Results}

\section{Morphological and ecological aspects}

One pair of macroscopically visible extrafloral nectaries (EFNs) was observed at the base of the abaxial surface of each leaves of Calolisianthus speciosus ( Fig. 1A and B) and C. pendulus. The EFNs in C. speciosus are bigger than in C. pendulus, and they are situated in depressions, whereas in C. pendulus the EFNs are in plane with the epidermal cells. In contrast, there are no macroscopically visible EFNs at the bases of C. amplissimus leaves ( Fig. 1A). A relatively concave small EFN was observed at the apex of the abaxial surface in all three species ( Fig. 1A). 

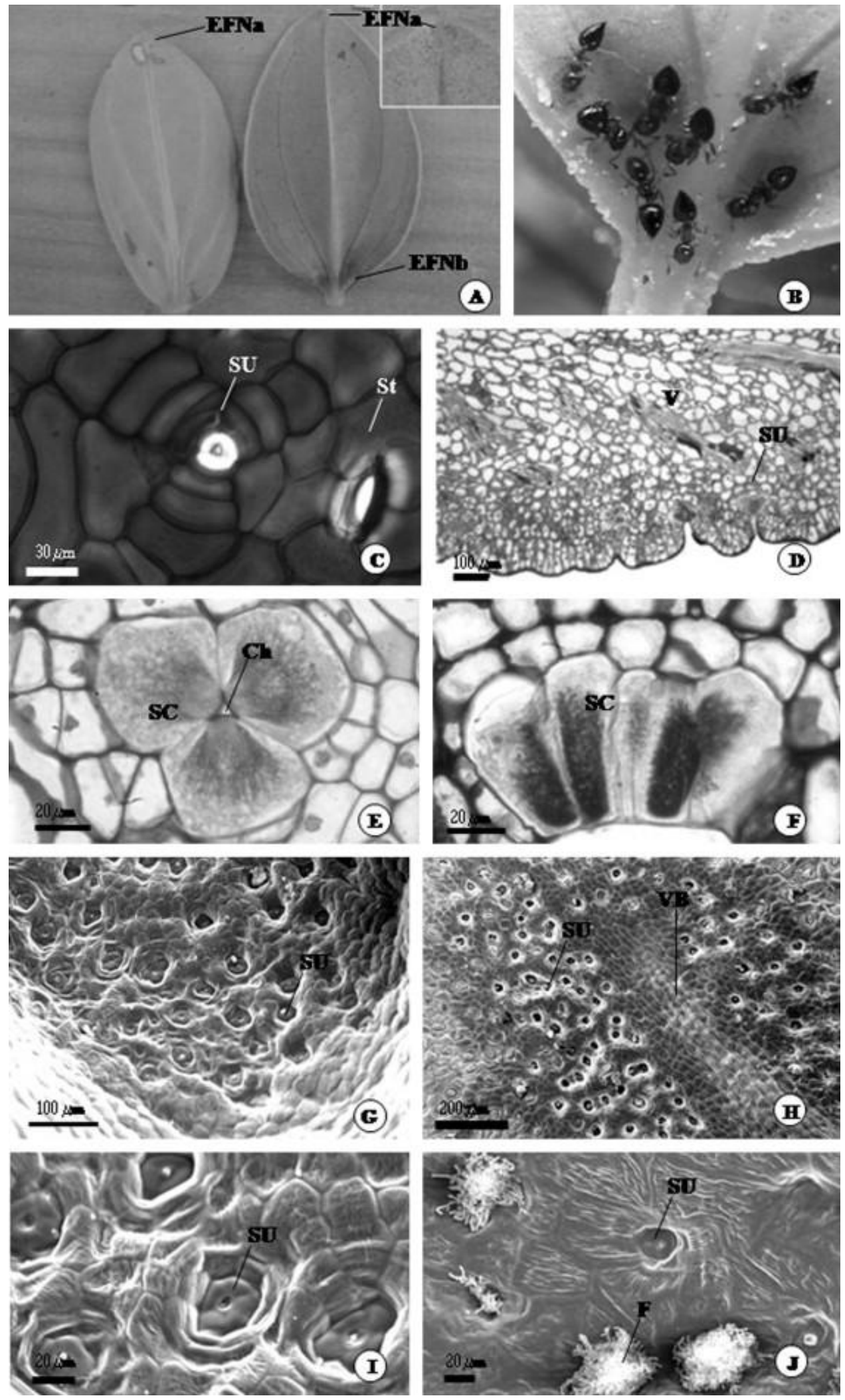

Fig. 1. Nectar secretory structures in Calolisianthus leaves. (A) Extrafloral nectaries (EFNs) at the apex of a C. amplissimus leaf (left) and at the apex and at the base of C. speciosus leaf (right and detail). (B) Patrolling ants on EFNs at the base of a C. speciosus leaf. (C) Cleared leaf of $C$. pendulus to observe secretory units and stomata on abaxial surface. (D) Vascularisation of the EFN of C. speciosus at the leaf base, abaxial surface. (E) Secretory unit of $C$. speciosus at the leaf base, abaxial surface (paradermic section). (F) Secretory unit of C. speciosus at the leaf base, abaxial surface (cross section). (G) Scanning electron microscope image (SEM) of a set of secretory units at the base a of C. speciosus leaf. (H) SEM of 
a set of secretory units at the apex of a C. speciosus leaf. (I) Detail of C. speciosus secretory units. (J) Set of secretory units at the base of a $\mathrm{C}$. pendulus leaf during the drier season. EFNa, extrafloral nectary at the apex of the leaf; EFNb, extrafloral nectary at the base of the leaf; SC, secretory cell; SU, secretory unit; St, stomata; Ch, channel; V, vascularisation; VB, vascular bundle; F, fungi.

EFNs at leaf base and apex started to secrete nectar before the leaves were fully expanded and they ceased secreting nectar in leaves that showed first signs of senescence. There was annual variation in the nectar production, as observed visually, that paralleled the production of new leaves. The secretory activities were more intense and continuous throughout the day during the rainy period (November to February) in C. speciosus and C. pendulus, when the leaves were younger; on the other hand, the amount of secretion was insignificant during the dry period (May to September), when the leaves were older.

Ants of the genera Crematogaster ( Fig. 1B), Camponotus, Brachymyrmex, and Linepithema often visited EFNs at the base of C. speciosus leaves during the rainy period. Ant nests were sometimes observed near $C$. speciosus plants or at the stem base. No ants were observed on leaves of C. amplissimus or C. pendulus.

\section{Nectar sugar analyses}

The extraflorally produced nectar of C. speciosus was composed of glucose, fructose, and sucrose. No other mono- or disaccharides were found. The concentrations were 3.34, 3.38 , and $1.04 \mu \mathrm{M}$ for glucose, fructose, and sucrose, respectively.

\section{Distribution of extrafloral nectaries}

Micromorphological investigations (Fig. 1G-J) and clearing (Fig. 1C) of leaves showed that the EFNs were composed by secretory units that when grouped together at the same site constituted conspicuous EFNs (Fig. 1G-J). Such secretory units were scattered also throughout the leaf on both adaxial and abaxial surfaces (Fig. 2B). Quantities and dispositions of these secretory units were different among species (Fig. 2A and B) and throughout the leaves of each species. C. speciosus had more secretory units at the base than at the apex of leaves $(t=$ $5.3629, \mathrm{P}<0.01)$ and more secretory units on the abaxial surfaces than on the adaxial surfaces $(t=3.7533, P<0.05)$. The same pattern was seen in $C$. pendulus: fewer secretory units at the apexes than at the bases of leaves $(t=115.5080, P<0.01)$ and fewer secretory units on the adaxial surfaces than on the abaxial surfaces $(t=3.5798, P<0.05)$. Contrasting with these species, there were only few secretory units at the base of $C$. amplissimus leaves. They were 
not enough to form a macroscopically visible EFN. However, many secretory units form a conspicuous EFN at the leaf apex of C. amplissimus. Also in this species, a great number of secretory units were found scattered throughout the leaf. They were present in higher numbers on the abaxial surface as compared to the adaxial surface $(t=3.4651, \mathrm{P}<0.05)$.

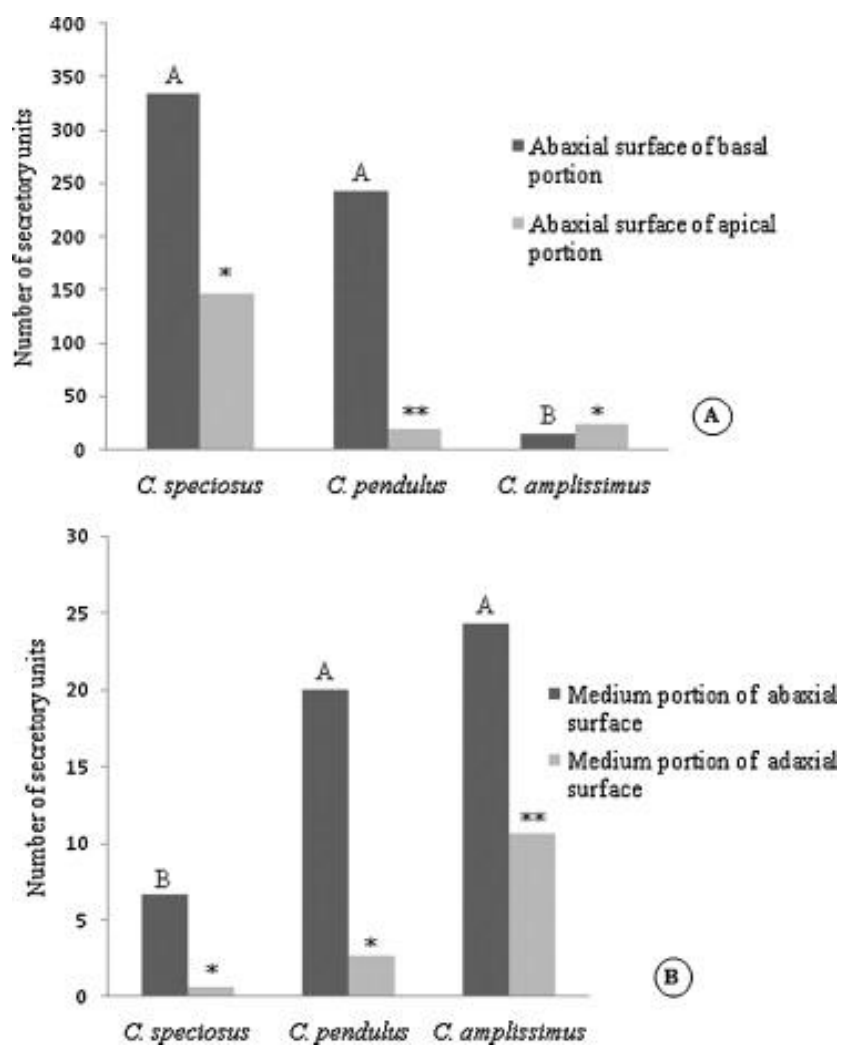

Fig. 2. Secretory units. (A) Distribution of secretory units on different portions (basal and apical) of Calolisianthus speciosus, C. pendulus, and C. amplissimus leaves. (B) Distribution of secretory units on different portions (abaxial and adaxial surfaces) of C. speciosus, C. pendulus, and C. amplissimus leaves. Means indicated by different letters or different number of asterisks are significantly different from one another ( $\alpha=5 \%$, ANOVA with Tukey's post hoc test).

\section{Light and electron microscopy}

Each secretory unit was formed by 3-8 rosette cells with a central channel from which the nectar was released (Fig. 1D). Some secretory units were formed by two concentric cell arrangements. The inner periclinal and anticlinal walls that did not enclose the channels of the secretory units were thick and impregnated with lipids and stained strongly with Toluidine Blue. The cytoplasm of these secretory cells was densely stained and sometimes granular (Fig. $1 \mathrm{E}$ and $\mathrm{F})$. There was sugar secretion inside the secretory cells, identified by the PAS test. Starch grains were not observed. The region of EFNs at the base of C. speciosus leaves was vascularised ( Fig. 1D), but the region of EFNs at the base of $C$. pendulus leaves was not. The EFNs at the leaf apex of all three species were not vascularised. 
During the dry season the central channels of several secretory units of the EFNs at the leaf base of C. speciosus and C. pendulus were filled up by hyphae of an hyphomycete ( Fig. 1J). During the rainy season the channels were not clogged by hyphae.

In the rainy period, when younger leaves could be collected, the secretory cells showed dense cytoplasms with a plenty of secretion, small vacuoles (Fig. 3A and B) and several mitochondria. In the inner periclinal and anticlinal walls that did not enclose the channel ingrowth structures occur (Fig. 3B). Moreover, the connection between the secretory cells and parenchyma cells is maintained by plasmodesmata (Fig. $3 \mathrm{C}$ ) and vesicular communication. Secretory cells are surrounded by epidermal and parenchyma cells that have mitochondria and also chloroplasts with starch grains. 

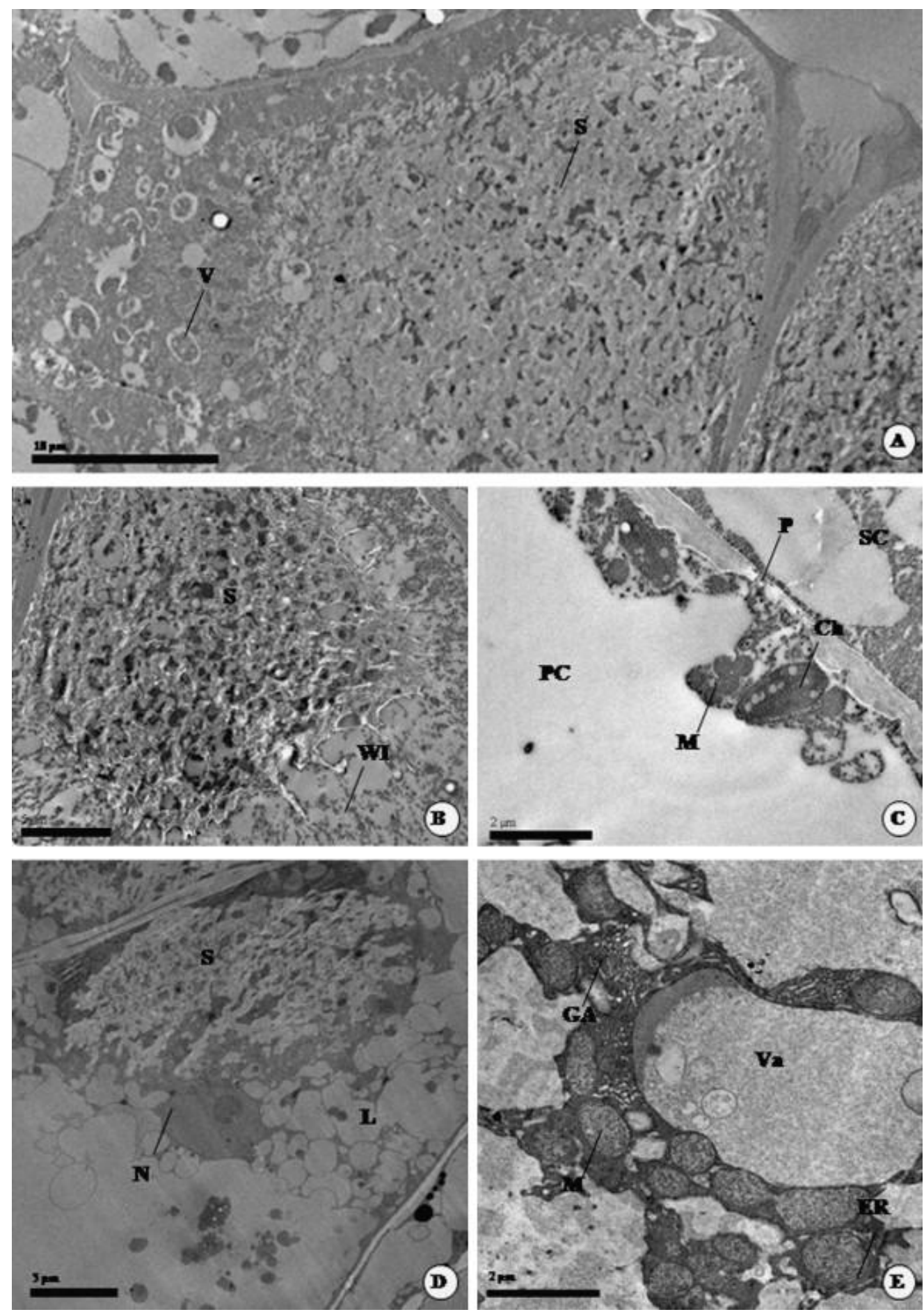

Fig. 3. Transmission electron microscope images (TEM) of nectar secretory structures in Calolisianthus leaves. (A-C) TEM of secretory cells in young leaves of $C$. speciosus during the wet season. (A) General view of a secretory cell and vesicles. (B) Detail of wall ingrowth in a secretory cell. (C) Detail of plasmodesmata between secretory cell and parenchyma cell. (D-E) TEM of secretory cells in old leaves of $C$. speciosus during the dry season. (D) A secretory cell with lipids and secretion. (E) A secretory cell with dictyosomes forming the Golgi apparatus, numerous mitochondria, vacuole, and segments of the endoplasmatic reticulum. S, secretion; V, vesicles; WI, wall ingrowth; PC, parenchyma cell; Ch, chloroplast; P, plasmodesmata; SC, secretory cell; M, mitochondria; GA, Golgi apparatus; ER, endoplasmatic reticulum; Va, vacuole; S, secretion; L, lipids. 
In the dry period, when only older leaves were available for sampling, the ultrastructure of secretory cells was characterized by an abundance of organelles, such as several dictyosomes forming the Golgi apparatus (Fig. 3E), plastids, numerous mitochondria (Fig. 3E), segments of the endoplasmatic reticulum (Fig. 3E), as well as conspicuous nuclei (Fig. 3D). Secretion and a large number of lipid droplets (Fig. 3D), scattered throughout the cytosol, were also identified.

The two main differences between the ultrastructures of secretory cells in younger and older cells was the change from dense secretion observed in nectaries of younger leaves (Fig. $3 \mathrm{~A}$ and $\mathrm{B}$ ) to lipid droplets observed in nectaries of older leaves (Fig. 3D), in addition to the larger numbers of visible organelles observed in older than in younger leaves.

\section{Discussion}

Extrafloral nectaries have not yet been investigated on the leaves of Calolisianthus species. Elias (1983) summarized that EFNs are absent in Gentianaceae and they are rare in the families of Loganiaceae and Apocynaceae of the Gentianales. Nevertheless, Struwe et al. (2002) mentioned the presence of glandular areas on sepals of Calolisianthus, but their occurrence on leaves was hitherto unknown. Despite being conspicuous, the size of the EFNs probably makes their identification difficult, as it is the case in other species as well ( Boughton, 1981).

The most common form of nectaries consists of nectariferous tissues formed by an epidermis and subtended by a specialised parenchyma (Fahn, 1979a), although the secretory tissue can be restricted to the epidermis (Evert, 2006). In the Calolisianthus species, the leaf EFNs are formed by a set of secretory units that are responsible for nectar secretion. Similar structures were observed in the calyxes of Irlbachia pendula, that is synonym of $\mathrm{C}$. pendulus ( Maas, 1985), and Vogel (1998) called them "nectarioles". Nectarioles can be isolated or aggregated, and they are small and inconspicuous structures formed by few cells. When aggregated, the nectarioles form an unusually conspicuous, macroscopic nectary ( Vogel, 1998).

EFNs present at the bases of leaves of C. speciosus and C. pendulus and the small EFN present at the apexes of leaves of all three species are flattened nectaries ( Elias, 1983). They are rounded or oval with a concave surface at the bases of leaves of $C$. speciosus, and have a flattened surface at the apexes of the leaves of $C$. amplissimus and at the bases and the apexes of leaves of $C$. pendulus. 
EFNs at the bases of leaves of $C$. speciosus and $C$. pendulus start secreting nectar when leaves are young, stopping it when the leaves become older. The difference in extrafloral nectar secretion is related to the age of the leaf and to the season of year, as young leaves are produced during the rainy period. In this time insect herbivore pressure is higher (Marquis et al., 2001). Therefore, a reduction of herbivory by EFN-mediated ant attraction, which latter we observed only in C. speciosus, may be understood as a selective advantage. In addition, it is not advantageous to continue investing in defence in the dry period as leaf senescence happens in this season. Besides, during this period old EFNs of $C$. speciosus and $C$. pendulus become attacked by fungi. These are hyphomycetes present on the pores of secretory units of C. speciosus and C. pendulus. Development of a fungus was also shown in old EFNs of Hymenaeae stigonocarpa/Fabaceae ( Paiva and Machado, 2006). Most probably, the fungi use the plant exudates, they may stimulate metabolic process, and can compete with pathogenic microorganisms ( Golubtsova et al., 2007). This has still to be studied in more detail.

Ants visit those EFNs that are located at the bases of C. speciosus leaves. Some of those ants make their nests near these plants, specifically at the bases of the stems. In this case, the plant represents the main area of ant attendance (Carrol and Janzen, 1973). Moreover, species of Camponotus, Crematogaster, Brachymyrmex, and Linepithema usually live in natural orifices or orifices made by other herbivores or make hollows inside stems with soft piths, as it is reported for a lot of species of plants ( Hölldobler and Wilson, 1990). Besides the defensive function, these ants can play an essential role in plant nutrition because the ant nests near or in the Calolisianthus stems may provide additional sources of nutrients ( Wagner, 1997). This may be particularly important increasing the fitness of $C$. speciosus, because soils of the campo rupestre are shallow, acid, sandy, and of low-fertility and water content ( Giulietti et al., 1987).

We observed that the secretory units vary in amount and localisation in each species. The presence of a pair of macroscopic EFNs formed by many secretory units at the base of $C$. speciosus and C. pendulus leaves and the absence of macroscopic EFNs at the base of C. amplissimus leaves may be a taxonomic attribute to distinguish Calolisianthus species. According to Metcalfe and Chalk (1979), nectaries may have taxonomic value because they facilitate the distinction among families and even species. It is important to emphasise that C. amplissimus and C. speciosus are very similar when they are in the vegetative stage of growth, which explains the importance of EFNs in the identification of the species. The aggregation of many secretory units at the bases of $C$. speciosus and $C$. pendulus leaves and the apexes of leaves of the three species, forming a conspicuous extrafloral nectary, may be a safety feature, 
as the nectar production would continue even if some glands were injured or destroyed ( Morellato and Oliveira, 1994).

The absence of ants patrolling C. amplissimus plants in the field may be explained by the fact that the nectarioles are scattered throughout the leaf blade and also by the small amount of nectar being secreted by each nectariole. As observed in Aphelandra ( McDade and Turner, 1997), large aggregates of nectaries produce large quantities of nectar. Furthermore, the predominance of the EFN and nectarioles on the lower leaf surfaces in the three species of Calolisianthus may contribute to reduction of nectar loss by evaporation, so that its availability for ant attendance is increased ( Paiva and Machado, 2006). Although the greater number of nectarioles at the bases of $C$. speciosus and $C$. pendulus leaves, forming conspicuous EFNs, may restrict ants to patrol only the basal portions of leaves, plants with improved nectar production concentrated at larger, localised nectaries might increase the attendance of ants to these important sites, in addition to possibly recruiting more ants (McDade and Turner, 1997). Thus, it is advantageous for a plant to restrict extrafloral nectar production to critical sites that are more vulnerable to herbivory ( McDade and Turner, 1997). On the other hand, the concentration of nectarioles at the leaf apex forming a conspicuous EFN may also be an advantage as the ants would have to patrol the whole leaf blade in order to find the nectar resource.

The lipid impregnation of the inner walls that did not surround the channel of the nectariole may be interpreted as a barrier to apoplastic transport, preventing secretion from reflux to adjacent parenchymatous cells (Lüttge, 1971). The thick lipid layer compels nectar release to the external environment (Fahn, 1979b), as it has already been observed in other secretory structures (Leitão et al., 2005 and Paiva et al., 2007). In Calolisianthus the nectar is released to the environment through the channel encircled by secretory cells, as it occurs in nectaries with stomata whose pores are the possible site of secretion ( Horner et al., 2003). In the studied species, the periclinal and the anticlinal walls that did not enclose the channel stained differently with Toluidine Blue; this confirms the data obtained by Vogel (1998) for calycinal nectaries of Calolisianthus (Irlbachia) pedunculatus. Vogel (1998) explains the superstaining of these regions as being a transfusion zone with a labyrinthine wall in which the secretion transport occurs. Moreover, as we found a great deal more glucose and fructose than sucrose in the nectar, we can infer that there is invertase action. This enzyme is essential to keep stable a sucrose concentration gradient sustaining the passive transport of nectar ( Fahn, 1988) from parenchyma to nectary cells.

The region of EFNs at the base of $\mathrm{C}$. speciosus leaf is vascularised, whereas the EFNs at the leaf apex and the nectarioles scattered throughout both leaf blade surfaces are not 
vascularised in all three species. The vascularisation might be responsible for intense production of nectar by the EFNs at the bases of C. speciosus leaves, whereas its absence might be responsible for the weak nectar production by EFNs at the apexes of leaves, by the nectarioles scattered throughout the leaves in the three species, and by the EFNs at the bases of C. pendulus leaves. Rudgers (2004) reported that vascular tissues are important for maintaining high secretion rates. Furthermore, the EFNs at the bases of $\mathrm{C}$. speciosus leaves are bigger than the EFNs at the apexes of the leaves and the isolated nectarioles throughout the leaves in the three species. According to Carlquist (1969), the amount of vascular tissue in a structure is directly proportional to its size; however, this is not the case for $\mathrm{C}$. pendulus because the EFNs at bases of its leaves are as big as the EFNs at the bases of $C$. speciosus leaves.

The ultrastructure of nectarioles in the rainy period showed many small vacuoles and numerous mitochondria as described in cells of the secretory tissues (Fahn, 1988), as well as wall ingrowth like that reported by Vogel (1998) for calycinal nectaries of Irlbachia (Calolisianthus) pedunculata. Fahn, 1979a and Fahn, 1979b also emphasized that the walls of secretory cells of many plants possess protuberances on their inner surfaces that may be numerous and form a thick labyrinthine layer. Such a cell wall could be called the secretion zone of the cell, where the pre-nectar is transported from parenchyma cells to secretory cells, as the functional feature of the wall ingrowth labyrinth is a high surface-to-volume ratio that facilitates an intensive trans-membrane flux of solutes ( Gawlik, 1984). Moreover, Fahn (1988) pointed out that the transport of pre-nectar occurs mainly in the symplast. This can be deduced also from the nectary structure of $C$. speciosus, as we identified plasmodesmata making connections between secretory and parenchyma cells. Export of nectar from protoplasts of the secretory cells might occur via eccrine secretion, not involving dictyosomes or ER, as these organelles were not identified in secretory cells during the rainy period. Eccrine secretion is also observed in Ancistrocactus scheeri ( Mauseth, 1982).

The ultrastructure of nectarioles in the drier season justified why it was impossible to collect nectar during this period, as the secretion cells were not more active. Most likely, the majority of organelles present in the older secretory cells are related to synthesis of lipid drops from nectar compounds. We observed plastids surrounded partly by endoplasmatic reticulum, a common feature of cells that make lipophilic substances (Fahn and Evert, 1974). A well developed Golgi apparatus, which is related to lipid production (Fahn, 1988), was also identified.

TEM observations can show ultrastructural changes that occur during the ontogenesis of the secretory structure (Horner et al., 2003 and Paiva, 2009). The ultrastructure of C. 
speciosus nectarioles confirmed the considerable differences between the secretory cells in young leaves and senescent leaves, explaining why the EFNs present on young leaves secrete nectar, whereas the EFNs present on senescent leaves do not. Despite the presence of abundant mitochondria, segments of endoplasmatic reticulum, and conspicuous nuclei that are commonly found in active nectar-producing tissue ( Fahn, 1988) the EFN units in older leaves do not more secret extrafloral nectar. It is likely that the great number of organelles in this ontogeny period of the nectariole result from the fact that the residual extrafloral nectar is transformed into lipid compounds by the Golgi apparatus. Re-absorption of such lipids may permit the plant to recycle part of the energy spent in the production of nectar ( Paiva and Machado, 2008).

The present first report of the anatomy and distribution of leaf nectaries in Calolisianthus species is also the first ultrastructural description of EFNs in Gentianaceae. These structures are rare in this family. Their occurrence in Calolisianthus species can be taken as a synapomorphic character developed in this genus. Search in related genera, in particular for only microscopically visible nectarioles or initial stages of them could be helpful demonstrating evolutionary ways bringing about such specialized structures and could possibly contribute to elucidate phylogenetic trends within the Gentianales order.

\section{Acknowledgements}

The authors are indebted to Ms. Cristina Ribeiro Marinho for her valuable suggestions, to Dr. José Henrique Schoereder for his help with ant identification, and to Dr. José Carmine Dianese for the fungi identification. The authors thank the technical team of the Laboratório de Microscopia Eletrônica da UNB, especially João Víctor de Oliveira Caetano and Ingrid Gracielle Martins da Silva. The authors are grateful to Dr. Lourdes Amaral for her help with the nectar analysis.

\section{References}

Berlyn, G.P., Miksche, J.P., 1976. Botanical Microtechnique and Cytochemistry. The lowa States Press, Ames. Boughton, V.H., 1981. Extrafloral nectaries of some phyllodineous Acacias. Aust. J. Bot. 29, 653-664.

Carlquist, S., 1969. Toward acceptable evolutionary interpretations of floral anatomy. Phytomorphology 19, 332-362.

Carrol, C.R., Janzen, D.H., 1973. Ecology of foraging by ants. Annu. Rev. Ecol. Syst. 18, $11-138$ 
Cuautle, M., Rico-Gray, V., 2003. The effect of wasps and ants on the reproductive success of the extrafloral nectaried plant Turnera ulmifolia (Turneraceae). Funct. Ecol. 17, 417-423.

do Nascimento, E.A., Del-Claro, K., 2010. Ant visitation to extrafloral nectaries decreases herbivory and increases fruit set in Chamaecrista debilis (Fabaceae) in a Neotropical savanna. Flora 205, 754-756.

Durkee, L.T., 1982. The floral and extrafloral nectaries of Passiflora. II. The extrafloral nectary. Am. J. Bot. 69, 1420-1428.

Elias, T.S., 1983. Extrafloral nectaries: their structure and distribution. In: Bentley, B.L., Elias, T.S. (Eds.), The Biology of Nectaries. Columbia University Press, New York, pp. 174-203.

Eiten, G., 1972. The cerrado vegetation of central Brazil. Bot. Rev. 38, 201-341.

Evert, R.F., 2006. Esau's Plant Anatomy: Meristems, Cells, and Tissues of Plant Body-Their Structure, Function, and Development, 3rd ed. John Wiley and Sons, New Jersey.

Fahn, A., 1979a. Secretory Tissues in Plants. Academic Press, London, p. 302.

Fahn, A., 1979b. Ultrastructure of nectaries in relation to nectar secretation. Am. J. Bot. 66, 977-985.

Fahn, A., 1988. Secretory tissues in vascular plants. New Phytol. 108, 229-257.

Fahn, A., Evert, R.F., 1974. Ultrastructure of secretory ducts of Rhus glabra L. Am. J. Bot. 61, 114.

Gawlik, S., 1984. An ultrastructural study of transmitting tissue development in pistil of Lilium leucanthum. Am. J. Bot. 71, 512-521.

Giulietti, A.M., Menezes, N.L., Pirani, J.R., Meguro, M., Wanderley, M.G.L., 1987. Flora da Serra do Cipó, Minas Gerais: Caracterizac, ão e lista das espécies. Bol. Bot. Univ. São Paulo 9, 1-115.

Golubtsova, Y.V., Glushakova, A.M., Chernov, I., 2007. The seasonal dynamics of yeast communities in the rhizosphere of soddy-podzolic soils. Eurasian Soil Sci. 40, 978-983.

Haridasan, M., 2000. Nutric, ão mineral das plantas nativas do Cerrado. Rev. Bras. Fisiol. Veg. $12,54-64$.

Hölldobler, B.,Wilson, E.O., 1990. Symbioses between ants and plants. In: Hölldobler, B., Wilson, E.O. (Eds.), The Ants. Harvard University Press, Cambridge, MA, pp. 530-556.

Horner, R.A.H., Cervantes-Martinez, T., Palmer, R.G., 2003. Floral nectary fine structure and development in Glycine max L. (Fabaceae). Int. J. Plant Sci. 164, 675-690.

Johansen, D.A., 1940. Plant Microtechnique. McGraw Hill, New York. Katayama, N., Suzuki, N., 2003. Changes in the use of extrafloral nectaries of Vicia faba (Leguminosae) and honeydew of aphids by ants with increasing aphid density. Ann. Entomol. Soc. Am. 96, 579-584.

Koptur, S., 1992. Extrafloral nectary-mediated interactions between insects and plants. In: Bernays, E. (Ed.), Insect-Plant Interactions. CRC Press, Boca Raton, pp. 81-129. 
Leitão, C.A.E., Meira, R.M.S.A., Azevedo, A.A., Araújo, J.M., Silva, K.L.F., Collevatti, R.G., 2005. Anatomy of the floral, bract, and foliar nectaries of Triumfetta semitriloba (Tiliaceae). Can. J. Bot. 83, 279-286.

Lüttge, U., 1971. Structure and function of plant glands. Ann. Rev. Plant Physiol. 22, 23-44.

Maas, P.J.M., Nilsson, S., Hollants, A.M.C., Ter-Welle, B.J.H., Person, J.G.M., VanHeusden, E.C.H., 1984. Systematic studies in neotropical Gentianaceae-the Lysianthus complex. Acta Bot. Neerl. 32, 371-374.

Maas, P.J.M., 1985. Nomenclatural notes on neotropical Lisyantheae (Gentianaceae). Proc. Kon. Ned. Akad. Wetensch., ser. C, 88, 405-412.

Maia, V., 1979. Técnica histológica. São Paulo, Atheneu.

Marquis, R.J., Diniz, I.R., Morais, H.C., 2001. Patterns and correlates of interspecific variation in foliar insect herbivory and pathogen attack in Brazilian Cerrado. J. Trop. Ecol. 17, 127-148.

Mauseth, J.D., 1982. Development and ultrastructure of extrafloral nectaries in Ancistrocactus scheeri (Cactaceae). Bot. Gaz. 143, 273-277.

McDade, L.A., Turner, M.D., 1997. Structure and development of bracteal nectar glands in Aphelandra (Acanthaceae). Am. J. Bot. 84, 1-15.

Medina, E., 1982. Physiological ecology of Neotropical savanna plants. In: Huntley, B.J., Walker, B.H. (Eds.), Ecology of Tropical Savannas. Springer, Berlin, pp. 308-335.

Mészáros, S., De Laet, J., Goethals, V., Smets, E., Nilsson, S., 2002. Cladistics of Gentianaceae: a morphological approach. In: Struwe, L., Albert, V.A. (Eds.), Gentianaceae: Systematics and Natural History. Cambridge University Press, Cambridge, pp. 310-376.

Meszáros, S., De Laet, J., Smets, E., 1996. Phylogeny of temperate of Gentianaceae: a morphological approach. Syst. Bot. 21, 153-168.

Metcalfe, C.R., Chalk, L., 1979. Anatomy of the Dicotyledons, vol. 1., 2nd ed. Oxford University Press, New York.

Morellato, L.P.C., Oliveira, P.S., 1994. Extrafloral nectaries in the tropical tree Guarea macrophylla (Meliaceae). Can. J. Bot. 72, 157-160.

O'Brien, T.P., Mccully, M.E., 1981. The Study of Structure Principles and Selected Methods. Termarcarphi Pty. Ltd., Melbourne.

Oliveira, P.S., 1997. The ecological function of extrafloral nectaries: herbivore deterrence by visiting ants and reproductive output in Caryocar brasiliense (Caryocaraceae). Funct. Ecol. 11, 323-330.

Oliveira, P.S., Freitas, A.V.L., 2004. Ant-plant-herbivore interactions in the neotropical cerrado savanna. Naturwissenschaften 91, 557-570. 
Oliveira, P.S., Leitão, H.F., 1987. Extrafloral nectaries: their taxonomic distribution and abundance in the woody flora of cerrado vegetation in southeast Brazil. Biotropica 19, 140148.

Paiva, E.A.S., 2009. Ultrastructure and post-floral secretion of the pericarpial nectarines of Erythrina speciosa (Fabaceae). Ann. Bot. 104, 937-944.

Paiva, E.A.S., Machado, S.R., 2006. Ontogênese, anatomia e ultra-estrutura dos nectários extraflorais de Hymenaea stigonocarpa (Fabaceae-Caesalpinioideae). Acta Bot. Bras. 20, 471482.

Paiva, E.A.S., Machado, S.R., 2008. The floral nectary of Hymenaea stigonocarpa (Fabaceae, Caesalpinioideae): structural aspects during floral development. Ann. Bot. 101, 125-133.

Paiva, E.A.S., Buono, R.A., Delgado, M.N., 2007. Distribution and structural aspects of extrafloral nectaries in Cedrela fissilis (Meliaceae). Flora 202, 455-461.

Pascal, L.M., Motte-Florac, E.F., Mckey, D., 2000. Secretory structures on the leaf rachis of Caesalpinieae and Mimosoideae (Leguminosae): implications for the evolution of nectary glands. Am. J. Bot. 87, 327-338.

Romero, R., 2002. Diversidade da Flora dos Campos Rupestres de Goiás, Sudoeste e Sul de Minas Gerais. In: Araújo, E.L., Moura, N.A., Sampaio, E.V.S.B., Gestani, L.M.S., Carneiro, J.M.T. (Eds.), Biodiversidade, conservac, ão e uso sustentável da flora do Brasil. Editora da Universidade Federal de Pernambuco, Recife, pp. 81-86.

Rudgers, J.A., 2004. Enemies of herbivores can shape plant traits: selection in a facultative antplant mutualism. Ecology 85, 192-205.

Rudgers, J.A., Gardener, M.C., 2004. Extrafloral nectar as a resource mediating multispecies interactions. Ecology 85, 1495-1502.

Scarano, F.R., et al., 2001. Four sites with contrasting environmental strees in southeastern Brazil: Relations of species, life form diversity, and geographical distribution to ecophysiological parameters. Bot. J. Linn. Soc. 136 (2001), 345-364.

Solereder, H., 1908. Systematic Anatomy of the Dicotiledons, vol. 1. Clarendon Press, Oxford.

Struwe, L., Albert, V.A., 2002. Gentianaceae: Systematics and Natural History. Cambridge University Press, Cambridge.

Struwe, L., Kadereit, J.W., Klackenberg, J., Nilsson, S., Thiv,M., Von-Hagen, K.B., Albert, V.A., 2002. Systematics, character evolution, and biogeography of Gentianaceae, including a new tribal and subtribal classification. In: Struwe, L., Albert, V.A. (Eds.), Gentianaceae: Systematics and Natural History. Cambridge University Press, Cambridge, pp. 21-309.

Vogel, S., 1998. Remarkable nectaries: structure, ecology, organophyletic perspectives II. Nectarioles. Flora 193, 1-29.

Wagner, D., 1997. The influence of ants nests on Acacia seed production, herbivory and soil nutrients. J. Ecol. 85, 83-93. 